\title{
ENHANCED CANCER CELL (HELA) KILLING EFFICACY OF MIXED ALPHA AND GAMMA IRON OXIDE SUPERPARAMAGNETIC NANOPARTICLES UNDER COMBINED AC (ALTERNATING CURRENT) MAGNETIC-FIELD AND PHOTOEXCITATION
}

\author{
Md. Shariful ISlam ${ }^{1}$, Yoshihumi KuSUmoto ${ }^{1 *}$, Md. Abdulla Al-Mamun ${ }^{1}$ \\ AND YUJI HORIE ${ }^{2}$ \\ ${ }^{I}$ Department of Chemistry and Bioscience, \\ ${ }^{2}$ Department of Electrical and Electronics Engineering, \\ Graduate School of Science and Engineering, Kagoshima University, \\ 1-21-35 Korimoto, Kagoshima 890-0065, Japan. \\ horie@eee.kagoshima-u.ac.jp; kusumoto@sci.kagoshima-u.ac.jp
}

\begin{abstract}
We synthesized mixed $\alpha$ and $\gamma-\mathrm{Fe}_{2} \mathrm{O}_{3}$ nanoparticles and investigated their toxic effects against HeLa cells under induced AC (alternating current) magnetic-fields and photoexcited conditions at room temperature. The findings revealed that the cellkilling percentage was increased with increasing dose for all types of treatments. Finally, 99\% cancer cells were destructed at $1.2 \mathrm{~mL}$ dose when exposed to combined AC magnetic-field and photoexcited conditions $\left(\mathrm{T}_{3}\right)$ whereas 89 and $83 \%$ of HeLa cells were killed under only AC magnetic-field induced $\left(T_{1}\right)$ or only photoexcited $\left(T_{2}\right)$ condition at the same dose.
\end{abstract}

ABSTRAK: Campuran $\alpha$ dan zarah $\gamma-\mathrm{Fe}_{2} \mathrm{O}_{3}$ bersaiz nano disintesiskan dan kesan toksidnya terhadap sel HeLa dikaji dibawah aruhan medan magnet arus ulang-alik (alternating current $(A C)$ ) dan keadaan photoexcited (proses ransangan atom atau molekul suatu bahan dengan penyerapan tenaga sinaran) pada suhu bilik. Penemuan mendedahkan bahawa peratusan sel yang musnah bertambah dengan pertambahan dos untuk semua jenis rawatan. Akhirnya, 99\% sel kanser dimusnahkan pada kadar dos $1.2 \mathrm{~mL}$ setelah didedahkan terhadap kombinasi medan magnet $A C$ dan keadaan photoexcited $\left(\mathrm{T}_{3}\right)$ dimana $89 \%$ dan $83 \%$ sel HeLa dimusnahkan dengan hanya di bawah aruhan medan magnet $A C\left(\mathrm{~T}_{1}\right)$ atau hanya pada keadaan photoexcited $\left(\mathrm{T}_{2}\right)$ pada kadar dos yang sama.

KEYWORDS: cancer; hyperthermia; iron oxide nanoparticles; heat dissipation, cytotoxicity; HeLa cell

\section{INTRODUCTION}

Preferential heating of certain organs or tissues to temperatures between $41{ }^{\circ} \mathrm{C}$ and 46 ${ }^{\circ} \mathrm{C}$ for cancer therapy is called " Hyperthermia ". Higher temperatures up to $56{ }^{\circ} \mathrm{C}$, which yield widespread necrosis, coagulation or carbonization (depending on temperature) is called "thermo-ablation" [1]. Magnetic iron oxide nanoparticles and their dispersions in various media have long been of scientific and technological interest. Maghemite $(\gamma-$ $\mathrm{Fe}_{2} \mathrm{O}_{3}$ ) is biocompatible and therefore is one of the most extensively used biomaterials for different applications like cell separation, drug delivery in cancer therapy, magnetic induced hyperthermia, MRI contrast agent, immunomagnetic separation and others [2]. Hematite has been used as photocatalyst for the degradation of chlorophenol and azo dyes 
[3] whereas maghemite and magnetite/carbon composites have been found to be useful for reducing the amount of undesirable $\mathrm{N}_{2}$ in fuel oil [4]. Superparamagnetic nanoparticles when exposed to an alternating magnetic field can be used to heat tumor cells to 41- 45 ${ }^{\circ} \mathrm{C}$, where damage for normal tissues is reversible while the tumor cells are irreversibly damaged [5]. In an alternating magnetic field, induced currents are generated in metallic objects, and as a consequence, heat is generated in the metal. Thus, when a magnetic fluid is exposed to an alternating magnetic field, the particles become powerful heat sources, destroying tumor cells since these cells are more sensitive to temperatures in excess of 41 ${ }^{\circ} \mathrm{C}$ than their normal counterparts [6]. In view of these, in this report we describe a method for the synthesis of superparamagnetic magnetite $\left(\mathrm{Fe}_{3} \mathrm{O}_{4}\right)$ nanoparticles with modification of the method as described by Omoike [7]. Then, $\mathrm{Fe}_{3} \mathrm{O}_{4}$ was transferred into mixed $\alpha$ and $\gamma-\mathrm{Fe}_{2} \mathrm{O}_{3}$ superparamagnetic nanoparticles with modification of the method as described by Sun et al. [8]. In our study, as-synthesized mixed $\alpha$ and $\gamma-\mathrm{Fe}_{2} \mathrm{O}_{3}$ nanoparticles were applied to HeLa cancer cell killing in different ways such as AC (alternating current) magneticfield induction $\left(\mathrm{T}_{1}\right)$, photoexcitation $\left(\mathrm{T}_{2}\right)$ and combination of both $\left(\mathrm{T}_{3}\right)$ to evaluate their cancer cell-killing potentiality.

\section{EXPERIMENTAL}

\subsection{Materials and Methods}

Typical syntheses of magnetic nanoparticles (MNPs) were carried out by using the reaction between $\mathrm{Fe}^{2+}$ and $\mathrm{Fe}^{3+}$ in co-precipitation method [8]. In this experiment, chemicals used for synthesis of $\mathrm{MNPs}$ were $\mathrm{FeCl}_{3}, \mathrm{HCl}, 25 \% \mathrm{NH}_{3}$ solution (Wako Pure chemical industries Ltd., Japan) and $\mathrm{FeCl}_{2}$ (Strem Chemicals, Newburyport). For HeLa cell culture, phosphate buffer saline (PBS), new born calf serum (NBS) (Invitrogen Corporation, Gibco), enzyme trypsine-EDTA (Gibco) solution, 0.5\% trypan blue stain solution (Nacalai Tesque, Inc., Kyoto, Japan) and minimum essential medium (MEM) solution (Sigma) were purchased and used as received.

\subsection{Synthesis and Formation of MNPs by Co-precipitation Method}

In a typical co-precipitation method, $\mathrm{FeCl}_{3}(2.6 \mathrm{~g})$ and $\mathrm{FeCl}_{2}(1.3 \mathrm{~g})$ were dissolved in nitrogen gas $\left(\mathrm{N}_{2}\right)$ purged $2.0 \mathrm{M}$ hydrochloric acid solution and magnetically stirred under a continuous flow of $\mathrm{N}_{2}$. The mixture was heated at $70^{\circ} \mathrm{C}$ for $30 \mathrm{~min}$ and again heated for another 5 min under a blanket of $\mathrm{N}_{2}$. Ammonia was added drop by drop to precipitate the MNPs and the black product formed was treated hydrothermally at $70^{\circ} \mathrm{C}$ for $30 \mathrm{~min}$. The resulting nanoparticles were subsequently separated from the reaction media under a magnetic field and washed three times with Millipore water before drying. Finally the MNPs were oven dried at $70^{\circ} \mathrm{C}$ for $3 \mathrm{~h}$ to get $\mathrm{Fe}_{3} \mathrm{O}_{4}$. It is well known that $\mathrm{Fe}_{3} \mathrm{O}_{4}$ can be oxidized to $\gamma-\mathrm{Fe}_{2} \mathrm{O}_{3}$, which can be further transformed into $\alpha-\mathrm{Fe}_{2} \mathrm{O}_{3}$ at higher temperature [7]. In this report, we simply transferred the $\mathrm{Fe}_{3} \mathrm{O}_{4}$ (Fig. 1a) to mixed $\alpha$ - and $\gamma-\mathrm{Fe}_{2} \mathrm{O}_{3}$ superparamagnetic nanoparticles by annealing it at $400^{\circ} \mathrm{C}$ for $6 \mathrm{~h}$ in the presence of oxygen.

\section{STRUCTURE AND MAGNETIC CHARACTERIZATION}

The as-synthesized MNPs were characterized using XRD, FE-SEM and TEM. AC magnetic field induced heating capability of MNPs were performed to observe the hyperthermia potentiality of the mixed $\alpha$ and $\gamma-\mathrm{Fe}_{2} \mathrm{O}_{3}$ by dispersing the nanoparticles in distilled water as well as in a MEM and magnetic hysteresis loops were measured by superconducting quantum interference device (SQUID, Quantum Design MPMS-5). 


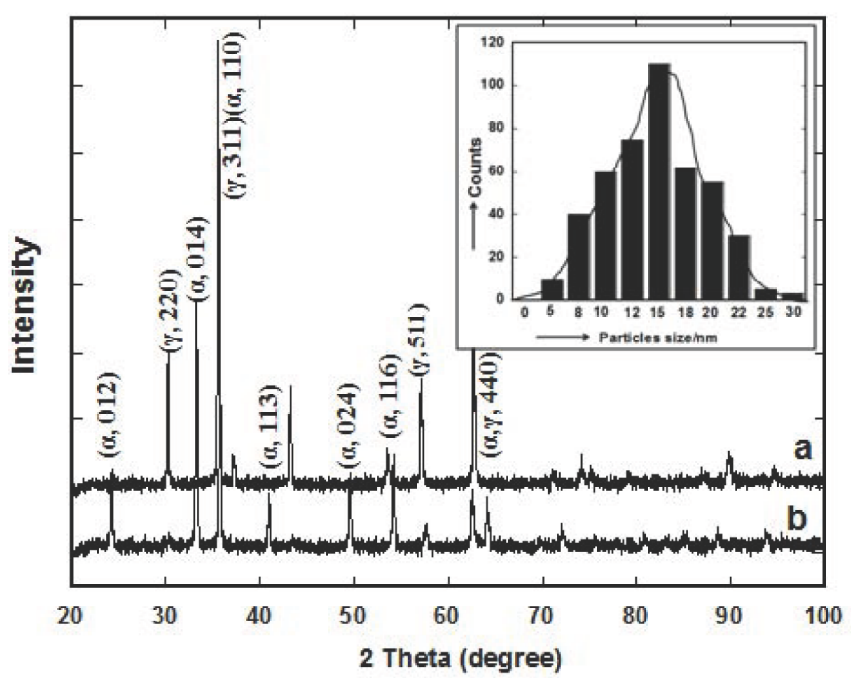

Fig. 1: XRD patterns of $\mathrm{Fe}_{3} \mathrm{O}_{4}$ (a) and mixed $\alpha$ and $\gamma-\mathrm{Fe}_{2} \mathrm{O}_{3}$ (b) and particle size distribution of mixed $\alpha$ and $\gamma-\mathrm{Fe}_{2} \mathrm{O}_{3}$ obtained from TEM data with approximation by a normal distribution (inset).

\section{IN-VITRO CYTOXICITY AND ANTI-CANCER ASSAY}

HeLa cells provided by the RIKEN BRC through the National Bio-Resource Project of the MEXT, Japan were cultured in MEM solution with $10 \%$ NBS in a humidified incubator with an atmosphere of $5 \% \mathrm{CO}_{2}$ in air at $37^{\circ} \mathrm{C}$ for 3 days. The in vitro cytotoxicity and anti-cancer effect of the mixed iron oxide nanoparticles against the HeLa cell line was evaluated by a trypan blue exclusion method [9]. In the experiment, the alternative current (AC) magnetic-field was created by using a magnetic oscillator with desired frequency and strength of $560 \mathrm{kHz}$ and $5.0 \mathrm{kA} / \mathrm{m}$, respectively, and a Xenon lamp (CERMAX 300-W LX300F, USA, ILC) with heat cut-off and band-pass filters (350-600 $\mathrm{nm}$ ) with an average intensity of $30 \mathrm{~mW} \mathrm{~cm}^{-2}$ was used for the light irradiation on HeLa cells. The light power was measured by a spectroradiometer (Model LS-100, EKO Instrument Co. Ltd.). A table rotator was used for the Petri dish to ensure the homogeneous light irradiation on the cells and temperature increment for the every dish was measured by a digital thermometer (Sato Keiryoki, Model SK-250WP II-R). To investigate the cytotoxicity of synthesized nanomaterials, one dish was used as control without any nanomaterials and the other five dishes were treated with different doses, like $0.2,0.4,0.8,1.0$ and $1.2 \mathrm{~mL}$ of nanoparticles colloidal solution per $5 \mathrm{~mL}$ of MEM solution where the actual colloidal solution concentration was $10 \mathrm{mg} / \mathrm{mL}$. A haemocytometer was used to estimate the total number of viable cells.

\section{RESULTS AND DISCUSSION}

Superparamagnetic $\mathrm{Fe}_{3} \mathrm{O}_{4}$ nanoparticles prepared by the co-precipitation method had high crystallization and good magnetic properties. SEM and TEM images (Fig. 2a, 2b) showed that the mean particle size was ca. $15 \mathrm{~nm}$. The as-synthesized $\mathrm{Fe}_{3} \mathrm{O}_{4}$ nanoparticles were transferred to mixed $\alpha$ - and $\gamma-\mathrm{Fe}_{2} \mathrm{O}_{3}$ superparamagnetic nanoparticles by annealing it 
at $400^{\circ} \mathrm{C}$ for $6 \mathrm{~h}$ in the presence of oxygen (Fig. 1) with the high crystallinity and mean particle size of ca. $15 \mathrm{~nm}$ (in set in Fig. 1, Fig. 2c, 2d).
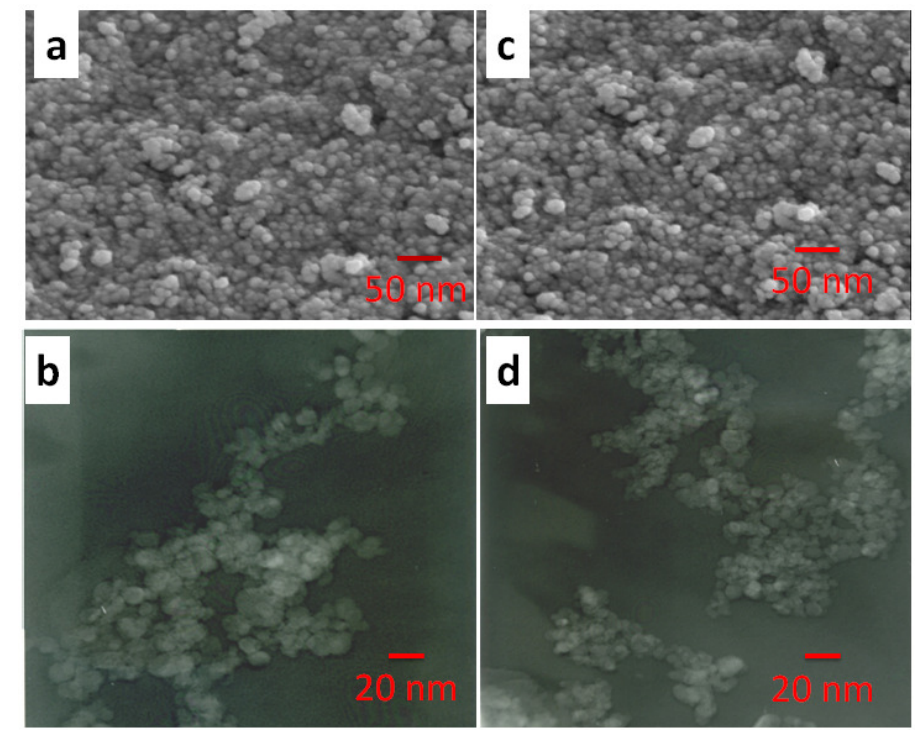

Fig. 2: SEM images of $\mathrm{Fe}_{3} \mathrm{O}_{4}$ (a) and mixed $\alpha$ and $\gamma-\mathrm{Fe}_{2} \mathrm{O}_{3}$ (c) and TEM images of $\mathrm{Fe}_{3} \mathrm{O}_{4}(\mathrm{~b})$ and mixed $\alpha$ and $\gamma-\mathrm{Fe}_{2} \mathrm{O}_{3}(\mathrm{~d})$, respectively.

Figure 1 shows X-ray diffraction (XRD) plots of the $\mathrm{Fe}_{3} \mathrm{O}_{4}$ (a), mixed iron (III) oxide $\left(\alpha-\right.$ and $\gamma-\mathrm{Fe}_{2} \mathrm{O}_{3}$ ) (b) nanoparticles of optimum properties. Heat dissipation of magnetic particles was evaluated by using an AC magnetic field generator. The heats generated from three distinct treatments $\left(T_{1}, T_{2}\right.$ and $\left.T_{3}\right)$ were evaluated by exposing various doses of mixed iron oxide MNPs suspension dispersed in a MEM to an AC magnetic field. The temperature increment of magnetite nanoparticles suspensions against different doses is shown in Fig. 3. The results revealed that highest temperature increment was obtained $48.7^{\circ} \mathrm{C}$ under combined $\mathrm{AC}$ magnetic-field induced and photoexcited $\left(\mathrm{T}_{3}\right)$ conditions at dose of $1.2 \mathrm{~mL}$ whereas for only AC magnetic field induced $\left(\mathrm{T}_{1}\right)$ or only photoexcited $\left(\mathrm{T}_{2}\right)$ condition the temperature increment was $45.5^{\circ} \mathrm{C}$ and $37.1^{\circ} \mathrm{C}$, respectively. Similar results were reported by Atsumi et al. [10] that maximum heat dissipation was observed for the MNPs suspension with an average particle diameter of $14 \mathrm{~nm}$, synthesized by the coprecipitation method. The toxic effect of mixed iron oxide nanoparticles was obtained by counting the percentage of viable cells after all the treatments (Fig. 4). The cancer cell viability was 59, 62 and $41 \%$ for $\mathrm{T}_{1}, \mathrm{~T}_{2}$ and $\mathrm{T}_{3}$, respectively, at a dose of $0.2 \mathrm{~mL}$. Similarly the findings (Fig. 4) revealed the cell killing percentage was increased with increasing dose for all types of treatments.

Finally, 99\% cancer cells were destructed at a dose of $1.2 \mathrm{~mL}$ when exposed to combined AC magnetic-field induced and photoexcited conditions $\left(\mathrm{T}_{3}\right)$ whereas 89 and 83 $\%$ of HeLa cells were killed in only AC magnetic-field induced $\left(\mathrm{T}_{1}\right)$ or only photoexcited $\left(\mathrm{T}_{2}\right)$ condition at the same dose (Fig. 4). However, instrumentation modeling of ACmagnetic field and photoexcitation, for the first time used by us indicates that ca. $15 \mathrm{~nm}$ (Fig. 1, inset) mixed iron oxide MNPs have maximum heating rates as well as cancer (HeLa) cell killing efficacy within the biologically safe frequency range. To the best of our understanding, the mechanism or reason for $99 \%$ HeLa cell killing under $\mathrm{T}_{3}$ condition can 
be ascribed to the combined or synergistic effect of AC magnetic-field induced hyperthermia and photocatalytic cytotoxicity.

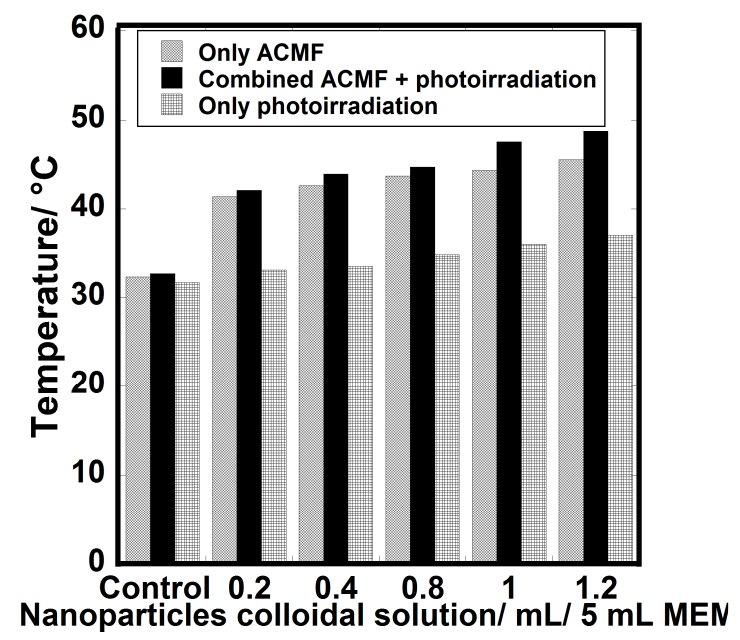

Fig. 3: Heat dissipation capability of mixed iron oxide nanoparticles under different conditions.

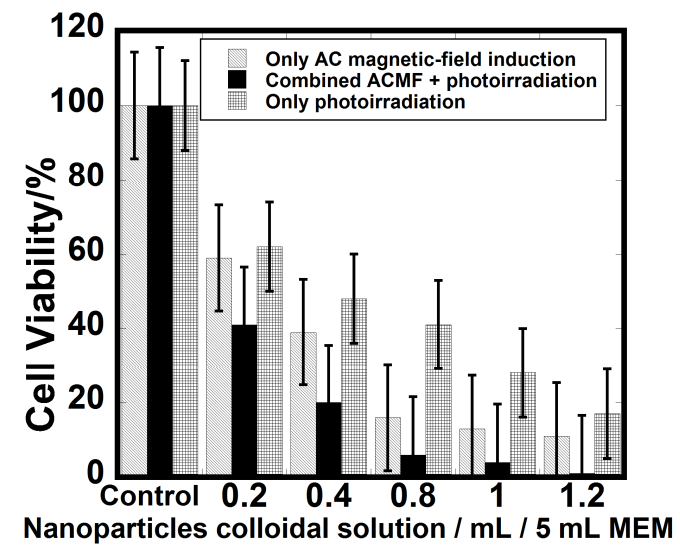

Fig. 4: Cancer cell killing efficacy of mixed iron oxide nanoparticles under three distinct conditions. Error bars are the standard errors.

\section{CONCLUSIONS}

We described the synthesis of superparamagnetic magnetite nanoparticles and the phase transfer to the mixed $\alpha$ and $\gamma-\mathrm{Fe}_{2} \mathrm{O}_{3}$ phase which due to their uniformity and monodispersity appear ideal for AC-magnetic field induced hyperthermia applications. To the best of our knowledge, for the first time we studied the cytotoxicity of mixed $\alpha$ and $\gamma$ $\mathrm{Fe}_{2} \mathrm{O}_{3}$ nanoparticles under the AC magnetic-field induced and photoirradiated conditions with almost $100 \%$ cancer cell killing efficacy. 


\section{ACKNOWLEDGEMENT}

The present work was partly supported by Grant-in-Aid for Scientific Research (B) (No.19360367) from Japan Society for the Promotion of Science (JSPS) and Grant-in-Aid for JSPS Fellows (No.20·00083). The authors are very happy to acknowledge to Assistant Professor Hirotaka Manaka, Department of Electrical and Electronics Engineering, Graduate School of Science and Engineering, Kagoshima University, for the analysis of the hysteresis loops of the prepared nanomaterials.

\section{REFERENCES}

[1] A. Jordan, R. Scholz, P. Wust, H. Fähling, R. Felix, "Magnetic fluid hyperthermia (MFH): Cancer treatment with AC magnetic field induced excitation of biocompatible superparamagnetic nanoparticles". Journal of Magnetism and Magnetic Materials, Vol. 201, 413-419, 1999.

[2] M. Chirita, I. Grozescu, " $\mathrm{Fe}_{2} \mathrm{O}_{3}$ - Nanoparticles, Physical Properties and Their Photochemical and Photoelectrochemical Applications". Chem. Bull. "POLITEHNICA" Univ. (Timisoara), Vol. 54, No.68, 1, 2009.

[3] J. Bandara, U. Klehm, J. Kiwi, "Raschig rings- $\mathrm{Fe}_{2} \mathrm{O}_{3}$ composite photocatalyst activate in the degradation of 4-chlorophenol and Orange II under daylight irradiation". Applied Catalysis B: Environmental, Vol.76, 73-81, 2007.

[4] M. Brebu, M.A. Uddin, A. Muto, Y. Sakata, C. Vasile, "Catalytic Degradation of Acrylonitrile-Butadiene-Styrene into Fuel Oil 1. The Effect of Iron Oxides on the Distribution of Nitrogen-Containing Compounds”. Energy \& Fuels, Vol. 15, 559-564, 2001.

[5] T. Neuberger, B. Schopf, H. Hofmann, M. Hofmann, B. von Rechenberg, "Superparamagnetic nanoparticles for biomedical applications: Possibilities and limitations of a new drug delivery system". Journal of Magnetism and Magnetic Materials, Vol. 293, No. 1, 483-496, 2005.

[6] An-Hui Lu, E. L. Salabas, S. Ferdi, "Magnetic Nanoparticles: Synthesis, Protection, Functionalization, and Application". Angewandte Chemie International Edition, Vol. 46, 1222-1244, 2007.

[7] A. Omoike, "Synthesis and Characterization of Tannic Acid Functionalized Magnetic Nanoparticles". ACS Symposium Series 996, Chapter 8, pp 90-107, 2008.

[8] S. Sun, H. Zeng, D. B. Robinson, S. Raoux, P.M. Rice, S. X. Wang, G. Li, "Monodisperse $\mathrm{MFe}_{2} \mathrm{O}_{4}(\mathrm{M}=\mathrm{Fe}, \mathrm{Co}, \mathrm{Mn})$ Nanoparticles". Journal of the American Chemical Society, Vol. 126, No. 1, 273-279, 2004.

[9] M. Abdulla-Al-Mamun, Y. Kusumoto, A. Mihata, M. S. Islam, B. Ahmmad, "Plasmoninduced photothermal cell-killing effect of gold colloidal nanoparticles on epithelial carcinoma cells". Photochemical \& Photobiological Sciences, Vol. 8, 1125 -1129, 2009.

[10] T. Atsumi, B. Jeyadevan, Y. Sato, K. Tohji, "Heating efficiency of magnetite particles exposed to AC magnetic field". Journal of Magnetism and Magnetic Materials, Vol. 310, 2841-2843, 2007. 